\title{
Mobbing a jeho role ve vnímání klimatu školy učiteli ${ }^{1}$
}

\author{
Tomáš Čech, Simona Dobešová Cakirpaloglu, \\ Jana Kvintová \\ Univerzita Palackého v Olomouci, Pedagogická fakulta
}

\begin{abstract}
Abstrakt: Kvalita výchovně-vzdělávacího procesu úzce navazuje na celkovou kvalitu klimatu školy a interpersonálních vztahů. Stále více je ve vztahu ke školnímu prostředí skloňován také pojem mobbing, tedy šikana na pracovišti, kdy se jedná o formy psychických útoků mezi kolegy-učiteli. Pokud se tento negativní fenomén ve školním prostředí vyskytuje, jedná se o závažný etický problém, který může zásadním způsobem ovlivňovat kvalitu klimatu ve škole a tím pádem také fungování školy jako výchovně-vzdělávací instituce. Hlavním cílem naší studie bylo zmapovat, jak pedagogové v základních školách vnímají své pracoviště a interpersonální vztahy $v$ něm. Dílčím cílem tohoto výzkumu bylo zjistit, jak vnímají klima školy učitelé, kteří se stali obět’mi nebo svědky šikany svých kolegů, v porovnání s pedagogy bez této negativní zkušenosti. K získání dat byla využita jednodimenzionální posuzovací škála měřící vnímání sociálního klimatu v pedagogickém sboru. $\mathrm{K}$ identifikování učitelů, kteři zažili šikanu na pracovišti (přihližejících a obětí) byl použit dotazník negativních aktů NAQ-R (Negative Acts Questionnaire-Revised). Výzkumný vzorek tvořilo 313 učitelů základních škol Olomouckého kraje, z toho 59 mužů a 254 žen. Výsledky šetření poukazují na to, že učitelé, kteří se ocitli v roli oběti či svědků mobbingu, vnímají klima pedagogického sboru významně negativněji než učitelé bez této negativní zkušenosti.
\end{abstract}

Klíčová slova: škola, klima školy, agrese, šikana na pracovišti, mobbing

\section{Workplace Bullying and Its Role in the Teacher's Perception of the School Climate}

Abstract: The quality of the education and training process is closely linked to the overall quality of the school climate and interpersonal relationships, and the concept of bullying in the workplace, is more and more related to the school environment when it involves forms of psychological attacks among teachers. It is logical that if this negative phenomenon occurs in the school environment, it is a serious ethical problem that can fundamentally influence the quality of the climate in the school and therefore also the functioning of the school as an educational institution. The main objective of our study was to map out how basic school teachers perceive their workplaces and interpersonal relationships within them. The partial aim of this research was to find out how school climate teachers perceived being victims or witnesses to the bullying of their colleagues compared to teachers without this negative experience. To obtain the data a one-dimensional assessment scale was used to measure the perception of the social climate among the teaching staff. A Negative Acts Questionnaire (NAQ-R) questionnaire was used to identify teachers who experienced bullying at the workplace (bystanders and victims). The research sample consisted

1 Studie vznikla díky podpoře grantového projektu IGA_PdF_2018_006 s názvem „Učitel jako obět’ šikany na pracovišti“. distribution, and reproduction in any medium, provided the original author and source are credited. 
of 313 basic school teachers from the Olomouc Region, of which 59 were men and 254 women. The results of the survey point to the fact that teachers who have been victims or witnesses of mobbing perceive the climate of the teaching staff significantly more negatively than teachers without this negative experience.

Keywords: school, school climate, aggression, bullying at the workplace, mobbing

\section{Klima školy a učitelského sboru jako východisko k empirii}

Pojem klima z řečtiny znamená podnebí, v přeneseném slova smyslu můžeme hovořit o podnebí prostředí. Ve vztahu ke školnímu prostředí můžeme hovořit o klimatu školy, ale také např. klimatu učitelského sboru či klimatu tř́dy. Vztah mezi prostředím, klimatem a atmosférou školy vymezuje Lašek (2007) ve svém schématu na obrázku 1.

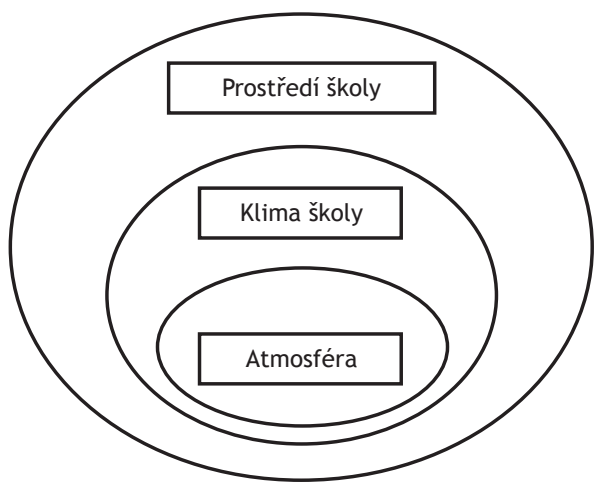

Obrázek 1 Vztah mezi prostředím, klimatem a atmosférou školy. Převzato z Lašek (2007)

Na utváření klimatu školy se podílí řada činitelů, a to např. místo, kde se škola nachází, velikost školy, počet žáků školy, zaměření školy (jazyky, sport...), složení učitelského kolektivu atp. Můžeme říci, že zahrnuje celkovou kvalitu prostředí ve škole, které má tyto dimenze (Grecmanová, 2008):

- ekologickou (materiální a estetické aspekty školy);

- demografickou (osoby ve škole z hlediska jejich kvalit a kompetencí);

- sociální (způsob komunikace a kooperace mezi osobami a skupinami ve škole);

- kulturní (hodnotové vzory a normy, poznávací a hodnoticí postupy, veřejné mínění, symbolika školy).

Klima nikdy nevzniká samo o sobě a najednou, ale vytváří se a dlouhodobě formuje. Grecmanová (2003) uvádí, že „klima vzniká jako odraz objektivní reality (prostředí) v našem subjektivním vnímání, prožívání a hodnocení jeho posuzovatelü“. Sestává z různých proměnných, které musí být nejdřive identifikovány a zkoumány 
s ohledem na vzájemné vztahy. Klima by mělo být tedy vždy posuzováno jako celek a nejen jako pouhá suma částí. To platí i u různých druhů klimatu školy (školní klima, klima učitelského sboru, komunikační klima atd.), jeho variant (emocionální klima vyučovací hodiny, pracovní klima, sociální klima školy ad.) a typů (školní klima s velkým zájmem o lidi, ale s malým zájmem o pracovní úkoly, demokratické klima, progresivní školní klima, pluralitní a otevřené školní klima ap.).

K významným složkám sociálního klimatu školy (a klíčovou pro téma našeho příspěvku) patři klima učitelského sboru, prezentované především interpersonálními vztahy a sociálními procesy, které v dané škole fungují. Učitelé ve škole nejsou ve styku jen s žáky a rodiči, ale pracují v konkrétní škole, pod vedením konkrétního ředitele, spolu s konkrétními kolegy ve sboru. Učitelský sbor chápeme jako svébytnou sociální skupinu typickou pro danou školu, jež má své sociální klima, vưdčí osobnosti, své vnímání, proživání, hodnocení a reagování na to, co se ve škole a kolem ní odehrává. Sociální klima učitelského sboru ovlivňuje jak sestava učitelů, tak osobnostní zvláštnosti ředitele včetně širšího vedení (Mareš \& Křivohlavý, 1995). Klima učitelského sboru, které v dané škole panuje, má zcela určitě vliv nejen na přistup a motivaci učitelů a na jejich postoj k dané škole, ale i ke kolegům, vedení, ostatním aktérům, žáky nevyjímaje. Jak uvádí Urbánek (2003a):

Při výzkumu učitele a jeho profesních charakteristik je problematika interpersonálních vztahů učitelů a sociálního klimatu sboroven zatím spíše opomíjena. Přitom ve smyslu zátěžových faktorů profese hrají profesní vztahy ve směru ke kolegům a zejména k managementu školy důležitou roli.

Toto tvrzení jsme přijali jako jednu z výzev při zpracování našeho příspěvku.

V jiné své publikaci Urbánek (2003b) uvádí, že „klima učitelského sboru vyjadřuje specifické kvality profesních i mimoprofesních interakcí mezi učiteli a současně prezentovanou kvalitu sociálních vztahů k vedení školy“. Halpin a Croft (1963) přihližející ke specifikům řizení školy a učitelského sboru rozlišili klima učitelského sboru jako otevřené a uzavřené.

- Otevřené klima je živé a energické. Pracovní úkoly a sociální potřeby učitelů jsou spolu v úzké souvislosti a jsou vyvážené. Ve škole pak převládá vzájemná důvěra, učitelé jsou zaujatí pro svou pedagogickou práci, jejich chování je otevřené a nepředstírané, mají vysokou pracovní morálku a navzájem spolupracují. Učitelský sbor není přetěžován, důraz se klade na osobní styk a autentičnost jednání. Ředitel jde svým podřízeným osobním příkladem, se svými podřizenými spolupracuje a mají společné cíle. Pravidla chování a chodu školy jsou jasná a stálá.

- Uzavřené klima tvoři opačný pól. Vyznačuje se frustrací lidí, učitelé nemají chut' se nějakým způsobem angažovat v pedagogické práci, jsou apatičtí a lhostejní k výsledkům své práce. Převládá vzájemná nedůvěra. Ředitel i učitelský sbor vykonávají předepsané činnosti pouze formálně. Pracovní úkoly a sociální potřeby nejsou vyvážené. Ředitel je neosobní, nejeví pochopení pro své podřizené, školu rídí formálně a byrokraticky a učitelé se v této situaci stahují do sebe a předstírají činnost (Halpin \& Croft, 1963; Kottkamp, Mulhern, \& Hoy, 1987). 
Stěžejní snahou každé organizace, tedy i školy, by mělo být vytvoření pozitivního klimatu, protože klima v jakékoliv instituci či skupině má kličový vliv nejen na psychiku člověka, ale významně ovlivňuje i pracovní výkonnost jednotlivce, potažmo celé skupiny. Při použití slovního spojení pozitivní klima má člověk na mysli, že jde o dobré klima, o dobré prostředí, ve kterém se dobře cítí, rád se $v$ něm pohybuje a rád $v$ něm pracuje. Na pozitivním klimatu školy se podílejí všichni aktéři - žáci, učitelé, vychovatelé, ředitel, nepedagogičtí pracovníci, provozní zaměstnanci i rodiče - a každý svým způsobem přispívá k tvorbě klimatu školy svým podílem, aniž by si to uvědomoval (Petlák, 2006).

Ke své činnosti potřebují pozitivní klima nejen žáci, ale samozřejmě i učitelé. K hlavním tvưrcům pozitivního klimatu školy patř́ ředitel a učitelský sbor. K uspokojení všech aktérů je nutné nahližet na pozitivní klima školy jak z hlediska žáků, tak učitelů, rodičů nebo veřejnosti (Čech \& Kantor, 2010). Na pozitivní klima z hlediska učitele má vliv celá řada činitelů, z jejichž množství uvádí Petlák (2006) následující:

... klidné tvořivé klima školy; klima, ve kterém se hledají nové pedagogicko-didaktické přístupy k žákům; demokratické vedení školy; úcta vedení školy k pracovníkům školy; vzájemná úcta a respekt v mezilidských vztazích; tvořivá spolupráce členů učitelského sboru; možnost seberealizace (studium, podpora inovativních př́stupů k výuce); celkově motivující prostředí.

Grecmanová (2008) s odkazem na zahraniční šetření, jež se zabývalo pozitivním klimatem školy, uvádí znaky pozitivního klimatu školy z hlediska učitelů takto:

... škola je pracoviště, v němž učitel rád pracuje a spolupracuje se žáky a jejich rodiči, ostatními kolegy, dobře vyučuje; škola umožňuje učiteli prožívat citový soulad a pocit sounáležitosti s jinými učiteli, úspěch v oboru a seberealizaci, svobodu a samostatnost $\checkmark$ práci, radost z pochvaly a uznání, ze spravedlivého hodnocení, spokojenost s daným stavem věcí.

Sekera a Janáček (1994) dále rozvíjejí úvahy:

Zvláště pedagogičtí pracovníci, vzhledem $\mathrm{k}$ charakteru své práce, jsou pravděpodobně více než lidé $v$ jiných profesích pod vlivem klimatu a atmosféry svých pracovních skupin. Je nesporné, že tato okolnost má nemalý vliv na pedagogickou činnost. Čím kvalitnější je klima a atmosféra $v$ pedagogickém sboru, tím spíše dochází $k$ identifikaci členů s uznávanými normami.

Tématem klimatu školy, resp. učitelského sboru, se zabývala řada autorů. V zahraničí mapujeme četné studie (např. Halpin \& Croft, 1963; Walberg, 1972; Thomas, 1976; Anderson, 1982; Pekrun, 1985; Kottkamp et al., 1987), z novějších publikací zmiňme Bulacha a Maloneho (1994), Vartiaovou $(1996,2003)$ nebo Kelleye, Thorntona a Daughertyho (2005). V českém prostředí můžeme řadit mezi přední autory Grecmanovou (2003, 2008), Ježka (2003) nebo Urbánka (2003, 2006, 2008 ap.) a další.

Školním klimatem se zabýval také Čech (2011) v rámci svého výzkumu zaměřeného na šikanu mezi učiteli. Z jeho výzkumu vyplývá, že bezmála tři čtvrtiny respondentů 
hodnotily sociální vztahy ve svých školách jako přátelské. $V$ těchto školách je předpoklad vzniku negativních forem jednání v pedagogickém sboru nízký, jelikož ve fungujících kolektivech jsou vztahy udržovány, podporovány a náznaky nežádoucího chování nejsou akceptovány. Jak však autor uvádí, jisté riziko lze vnímat u necelé pětiny dotazovaných, pro které jsou vztahy korektní, nikoli přátelské, což může změnit případný konflikt, který může snadněji vyvolat jednání se znaky mobbingu. Rizikové jsou pak školy, ve kterých necelých osm procent pedagogů označilo vztahy za negativní. $V$ takovém prostředí lze očekávat časté konflikty, neschopnost tyto problémy navzájem řešit a logicky jde o platformu, kde se negativní formy jednání objeví snadněji. $V$ rámci studie se podařilo verifikovat vztah mezi zkušeností $s$ mobbingem, resp. bossingem, a kvalitou klimatu školy, které je obět'mi šikany hodnoceno významně negativněji. To se stalo dalším z východisek pro koncipování naší empirické studie.

\section{Mobbing - teoretické ukotvení v české a mezinárodní terminologii}

Mobbing bývá obecně vymezován jako specifická forma šikanování, která se odehrává mezi jedinci v přibližně stejné společenské pozici. Ve vymezení odborné terminologie vztahující se $k$ tomuto tématu panuje určitá nejednotnost. Můžeme se setkat s termíny, jako jsou např. bullying, harassment, mobbing či abusive behavior. Přikláníme se k anglofonnímu vymezení, tzn. šikanování na pracovišti (bullying), ačkoli se $v$ českém prostředí setkáváme spí̌̌e s pojmem mobbing (Beňo, 2003; Svobodová, 2008; Čech, 2010; Cakirpaloglu et al., 2016).

0 rozšíření pojmu mobbing ve společenských vědách se zasloužil především německý profesor Heinz Leymann (1932-1999), který od roku 1955 žil a pracoval ve Švédsku a ve své praxi lékaře a psychologa se počátkem osmdesátých let minulého století věnoval pacientům $s$ komunikačními a vztahovými problémy na pracovišti. Ze svých pozorování, která prováděl společně s Anneli Gustafssonovou v letech 1982-1983 ve Švédsku, vyvodil, že se způsobem „útočící smečky“ chovali v mnoha př́padech pracovníci ke svému kolegovi (Leymann, 1996).

Šikana na pracovišti představuje vážnou formu obtěžování, která je považována za extrémní přičinu sociálního stresu v pracovním prostředí (Zapf et al., 1999). Podle Leymanna (1996, s. 168) toto chování představuje neprátelské projevy agrese na pracovišti, přičemž je zaměstnanec systematicky vystaven nepřátelství ze strany jednotlivce nebo skupiny, zatímco prožívá bezmoc a strach z vyloučení ze skupiny spolupracovníků. Další definici uvádí Einarsen s kolegy (2011, s. 22), podle nichž takové chování zahrnuje obtěžování, porušování a sociální vyloučení zaměstnance nebo negativní ovlivňování práce zaměstnance. Podle těchto autorů danou aktivitu lze považovat za mobbing, pokud se takové chování vyskytuje pravidelně (např. jednou týdně) a opakuje se (kupř. za posledních šest měsíců). Během tohoto stupňovitého procesu se obět' dostává do podřízené pozice a je cílem neustálých agresivních útoků. 
I když se šikana na pracovišti projevuje v různých formách, vždy se jedná o ponižující chování jednotlivce nebo skupiny vǔči jedinci (anebo skupině), který se nemůže této situaci vyhnout, není schopen se jí účinně bránit a má tyto znaky:

- opakované, dlouhodobé ubližování;

- asymetričnost;

- hostilita (Einarsen et al., 2011; Lutgen-Sandvik, 2013).

O šikaně hovoříme tehdy, když se negativní jednání pravidelně opakuje, obvykle jednou týdně, a musí se vyskytovat v určitém časovém období, dle definice nejméně půl roku. Určité formy negativního chování jsou součástí každodenního pracovního života, nicméně pokud se jejich frekvence systematicky opakuje a stupňuje, pak se jedná o šikanování (Einarsen et al., 2011). Tyto nežádoucí formy neetického chování na pracovišti se mohou pohybovat od jemných, velice subtilních projevů negativního jednání až po úmyslné útoky na jedince (např. zadržování informací, které ovlivňují pracovní výkon zaměstnance, opakované připomínání omylů a chyb či přehnaná kontrola). Druhým znakem, který odlišuje mobbing od jiných forem agresivního chování, je nerovnováha moci mezi agresorem a obětí (Leymann, 1996). Nerovnováha se projevuje $v$ bezmocnosti oběti bránit se, zastavit či předejít zneužívání. A jako poslední aspekt charakterizující mobbing je záměr pachatele $s$ cílem ubližit oběti (Einarsen et al., 2011).

Jedná se tedy o závažný problém a jev, kdy dochází k porušování sociálních norem spojenému s omezováním základních lidských práv a možnými až tragickými důsledky pro obět' tohoto jednání a jeho osobnost.

Shrneme-li doposud zmíněné poznatky o mobbingu, jde o formu psychického týrání, kdy je systematicky, cílevědomě a především opakovaně veden útok na určitou osobu. $\mathrm{K}$ psychoteroru se využívá diskriminujícího a degradujícího přístupu, nadměrné kritičnosti, zesměňňování, drobných či větších intrik, kterým se nemưže obět' bránit běžnými volními mechanismy. Bývá narušována psychická rovnováha oběti, která se projevuje v pracovní výkonnosti a může vést k závažným poruchám $v$ integritě osobnosti jedince, a to $v$ rovině psychické (deprese, poruchy koncentrace, pochybnosti o sobě, stavy úzkosti až po myšlenky na sebevraždu), psychosomatické (poruchy srdeční a poruchy krevního oběhu, svíravé pocity při dýchání, bolesti hlavy, šíje a zad, kožní onemocnění a nemoci zažívacího traktu), psychosociální (neschopnost navazovat sociální vztahy a vazby, uzavřenost, zhoršení mezilidských vztahů, nedůvěra, narušení soukromého života atp.) a v neposlední řadě $v$ rovině ekonomické ve formě sniženého pracovního výkonu, zvýšené nemocnosti a s tím spojených vysokých nákladů na léčbu (Svobodová, 2008; Čech, 2011; Høgh et al., 2011; Vignoli et al., 2015; Cakirpaloglu et al., 2017; Dobešová Cakirpaloglu, Čech, \& Kvintová, 2017).

Kromě výše uvedených důsledků mobbingu se můžeme setkat i s dalšími faktory, které jsou ve vztahu s mobbingem odhalovány ve výzkumech, jedná se např. o souvislost s vyšším výskytem absentérismu (Nielsen \& Einarsen, 2012), se snižováním loajálnosti k organizaci (Hoel \& Cooper, 2000), s nižší mírou pracovní spokojenosti 
(Moayed et al., 2006; Nielsen \& Einarsen, 2012) a v neposlední řadě i s vyšší fluktuací zaměstnanců.

Šikana na pracovišti je stále poněkud zjednodušeně viděna jako neetická forma komunikace mezi agresorem a obětí, přičemž se přehliží role přihlížejících neboli svědkư šikany. Většina studií věnovaných problematice šikany na pracovišti se tak zaměřuje primárně na oběti (Čech, 2011; Einarsen et al., 2011; Cakirpaloglu et al., 2017). V posledních letech se objevují výzkumy, které si všímají možného negativního vlivu konfliktních situací na všechny bezprostřední aktéry, a to dokonce i na přihližející (Paull, Omari, \& Standen, 2012). Stále více autorů pohlíží na přihlížející šikany jako na jedince, kteří jsou aktivně či pasivně zapojeni do procesu šikany, kde zastávají různou roli, od pomáhání oběti, po umožňování, či dokonce napomáhání v šikanujícím chování agresora (Keashly \& Jagatic, 2011; Paull et al., 2012). Obdobně jako u oběti, i zde se objevují dopady šikany na přihlížejícího, kupř. vyšší hladina stresu, snižení pracovní spokojenosti, větší fluktuace či menší efektivita na pracovišti (Vartia, 2001; Salin, 2001). Existují dokonce i studie potvrzující zvýšenou míru výskytu depresivních symptomů u přihlížejících (Kiwimäki et al., 2003).

\section{Metodologie}

Hlavním cílem této studie bylo zjistit, jak pedagogové působící v základních školách vnímají pracovní klima svého pracoviště a interpersonální vztahy v něm s ohledem na různá diferenciační kritéria (pohlaví, pracovní pozice, délka praxe). Významným diferenciačním kritériem je negativní zkušenost s mobbingem, a to at' již přímá ( $v$ roli oběti), nebo nepřimá ( $v$ úloze svědka). Dílčím cílem je pak zjistit, jak vnímají sociální klima ve škole učitelé, kteři se stali obět'mi nebo svědky šikany svých kolegů v porovnání s učiteli bez této negativní zkušenosti.

Bylo stanoveno pět hypotéz, které byly následně verifikovány. $Z$ důvodu eliminace duplicity uvádíme znění hypotéz pouze ve výsledkové části.

\subsection{Výzkumný soubor}

Výzkum byl realizován v období od října do prosince 2017 a byl koncipován jako kvantitativní šetření. Sběr dat probíhal elektronicky prostřednictvím systému Google Forms, který splňoval metodologicko-výzkumná kritéria relevantnosti on-line šetření (např. vysoká míra zabezpečení, možnost archivace a kódování během přenosu dat, přístup přes vygenerované heslo). Byl vytvořen seznam všech základních škol Olomouckého kraje (256), náhodným výběrem (losováním) bylo vybráno 100 škol, jejiž učitelé byli následně osloveni a požádáni o spolupráci. $V$ rámci sběru dat jsme obdrželi 313 vyplněných dotazníků, žádný dotazník nebyl vyřazen z důvodu chybějících dat.

Soubor respondentů byl tedy tvořen 313 učiteli pracujícími na 1. a 2. stupni základních škol, konkrétně to bylo 129 učitelů z 1 . stupně $Z$ Š, 78 učitelů z 2 . stupně $Z \check{S}$ 
116 a 106 učitelů působilo na 1. i 2. stupni. Věkové rozpětí sledovaného vzorku se pohybovalo od 20 do 65 let (průměrný věk 44,41 roku; SD 10,51). Délka praxe od jednoho do 44 let (průměrná délka praxe byla 19,31; SD 11,95). Účast na výzkumném šetření byla dobrovolná a respondentům byla zajištěna anonymita při sběru dat.

\subsection{Výzkumné metody}

Ke sběru dat byly použity následující metody:

Jednodimenzionální posuzovací škála měřicí vnímání klimatu učiteli (převzato od Čech, 2011). Sociální klima v pracovním kolektivu školy bylo zjišt’ováno pomocí jednodimenzionální posuzovací škály, která měři vnímání klimatu učiteli. Je to škála, která se použivá pro měření intenzity psychologických a sociologických postojů jedince $k$ dané situaci. Respondenti se na 14 bipolárních adjektivech prostřednictvím osmistupňové škály vyjádří, jak vnímají skupinové klima ve svém pracovním kolektivu. Stupnice je koncipována jako osmibodová, kdy s ohledem na utváření škál bylo dbáno, aby pokud možno jednotlivé protipóly byly podchyceny antonymy bez totožného slovního základu. Škála začíná pozitivní charakteristikou klimatu a pokračuje do protipólu s negativní charakteristikou. Cronbachovo a pro 14 položek dotazníku bylo 0,97 , což svědčí o vysoké reliabilitě použité metody.

Sebeposuzovací měření výskytu šikany. Pro identifikaci výskytu a forem mobbingu byla použita revidovaná verze Dotazníku negativních aktů (dále jen NAQ-R), která má 23 položek (Einarsen, Hoel, \& Notelaers, 2009). Respondenti vyznačují své odpovědi na pětibodové Likertově škále, kde zaznamenávají frekvenci šikanujícího chování, to znamená, jak často se setkali s uvedeným typem chování během posledních šesti měsíců. Behaviorální aspekty mobbingu měří položky 1 až 22 , sebeposuzující aspekt mobbingu je vyjádřen v položce 23 . Na české populaci byl dotazník validizován ve studii Cakirpaloglu et al. (2016). Cronbachovo a pro 22 behaviorálních položek bylo 0,94 , což vypovídá o vysoké reliabilitě české verze NAQ-R.

Pro účely naší studie byla $z$ důvodu identifikace obětí mobbingu ve vztahu k vnímání pracovního klimatu použita pouze poslední sebeposuzovací položka dotazníku. Respondentovi je zde umožněno, aby sdělil vlastní zkušenost a vyjádřil se, zda se cítí $\checkmark$ pozici oběti mobbingu $v$ souladu s teoretickou definicí, která je nedílnou součástí této položky.

Pro identifikaci přihlížejících (neboli svědků šikany) sloužila další položka, kde byla uvedena definice šikany a respondent na dichotomní škále ano-ne označil, zda se během posledních šesti měsíců stal svědkem šikany na pracovišti. Pro úplnost uvádíme doslovné znění použité definice:

Byl/a jste někdy svědkem/kyní šikanování kolegy na pracovišti? Šikanou označujeme situaci, ve které jedna nebo více osob vnímají, že jsou v průběhu delší doby vystaveni negativnímu pưsobení ze strany jedné či více jiných osob; ohrožená osoba má potíže ubránit se před těmito aktivitami. Přitom jednorázový incident nepovažujeme jako šikanu na pracovišti. 
Sociodemografický dotazník. Sociodemografický dotazník obsahoval demografické údaje, jako jsou věk, pohlaví, délka pedagogické praxe, doba pưsobení na současné škole, kraj, velikost školy, specifická pozice v rámci školy.

\subsection{Zpracování a vyhodnocení dat}

V první fázi proběhlo zpracování dat ve formátu xls, který je kompatibilní s programem MS Excel 2013, do něhož lze také bez problémů exportovat data získaná prostřednictvím elektronických dotazníků.

V druhé fázi byla provedena formální a logická kontrola dat. Další zpracování dat již probíhalo pomocí statistického softwaru STATISTICA verze 13. Analýza rozložení jednotlivých výsledků potvrdila normální distribuci dat a z toho důvodu byla zvolena parametrická statistika, zejména popisná statistika a $t$-test. Testy byly provedeny na $5 \%$ hladině významnosti.

\section{Výsledky}

V první fázi prezentujeme výsledky, které se budou týkat vnímání sociálního klimatu u celého výzkumného souboru. Zaměřili jsme se na analýzu odpovědí v dotazníku zachycující sociální klima ve školním prostředí celého zkoumaného vzorku.

Přehled detailního profilu sociálního klimatu celého vzorku prezentuje tabulka 1. $\mathrm{Na}$ základě těchto výsledků můžeme konstatovat, že téměř tři čtvrtiny respondentů vnímají sociální klima pozitivně, přičemž nejčetněji jsou zastoupeny behaviorálními adjektivy úspěšné, přijímající a přátelské. Neutrálně vnímá sociální klima $20 \%$ respondentů a téměř 7 \% dotázaných vnímá sociální klima spíše či velmi negativně (antonyma uvedených adjektiv). Mezi nejčetněji zastoupenými adjektivy jsou neupřímnost, neférovost a emoční chlad.

Tabulka 1 Profil sociálního klimatu celého vzorku - procentuální zastoupení

\begin{tabular}{lcccccc}
\hline & $\mathbf{N}$ & $\begin{array}{c}\text { SN až VN } \\
(\%)\end{array}$ & $\mathbf{N}$ & $\begin{array}{c}\text { NH } \\
(\%)\end{array}$ & N & $\begin{array}{c}\text { SS až VS } \\
(\%)\end{array}$ \\
\hline Přátelské & 12 & 3,8 & 56 & 12,5 & 245 & 78,3 \\
Přijímající & 15 & 4,8 & 52 & 12,8 & 246 & 78,6 \\
Uklidňující & 18 & 5,8 & 82 & 18,9 & 213 & 68,1 \\
Produktivní & 13 & 4,2 & 67 & 15,7 & 233 & 74,4 \\
Upř́mné & 36 & 11,5 & 84 & 19,8 & 193 & 61,7 \\
Kooperativní & 23 & 7,4 & 66 & 15,0 & 224 & 71,6 \\
Zajímavé & 15 & 4,8 & 58 & 15,8 & 240 & 76,7 \\
Podporující & 17 & 5,4 & 55 & 12,8 & 241 & 77,0 \\
Úspěšné & 10 & 3,2 & 56 & 13,1 & 247 & 78,9 \\
\hline
\end{tabular}




\begin{tabular}{lllllll}
\hline Transparentní & 28 & 9,0 & 57 & 14,1 & 228 & 72,8 \\
Férové & 30 & 9,6 & 64 & 15,3 & 219 & 70,0 \\
Citové & 29 & 9,3 & 54 & 11,5 & 230 & 73,5 \\
Volné & 20 & 6,4 & 67 & 14,7 & 226 & 72,2 \\
Tvořivé & 21 & 6,7 & 61 & 13,4 & 231 & 73,8 \\
Relativní podíl & 20,5 & 6,6 & 62,8 & 20,1 & 229,7 & 73,4 \\
\hline
\end{tabular}

Pozn.: SN až VN - spíše nesouhlasím až velmi nesouhlasím, NH - neutrální hodnocení, SS až VS spíše souhlasím až velmi souhlasím, $N$ - absolutní četnost.

Tabulka 2 prezentuje srovnání vnímání sociálního klimatu tří skupin respondentů s ohledem na jejich zkušenosti s mobbingem, obrázek 2 pak názorně vizualizuje zjištěné diference u sledovaných skupin. $Z$ výsledků mediánů a průměrných dosažených hodnot na škále sociálního klimatu vyplývá, že oběti vnímají sociální klima nejméně pozitivně $(M e 67, M 66,2) \vee$ komparaci se svědky mobbingu $(M e 77, M 74,7)$ a ostatními respondenty bez zkušenosti s mobbingem (Me 94, $M$ 89,8).

Tabulka 2 Komparace vnímání sociálního klimatu dle zkušenosti s mobbingem

\begin{tabular}{lcccccc}
\hline & $N$ & Medián & Průměr & SD & Min & Max \\
\hline Oběti & 13 & 67 & 66,2 & 28,3 & 21 & 102 \\
Svědci & 29 & 77 & 74,7 & 21,3 & 21 & 103 \\
Ostatní & 281 & 94 & 89,8 & 17,7 & 30 & 112 \\
\hline
\end{tabular}

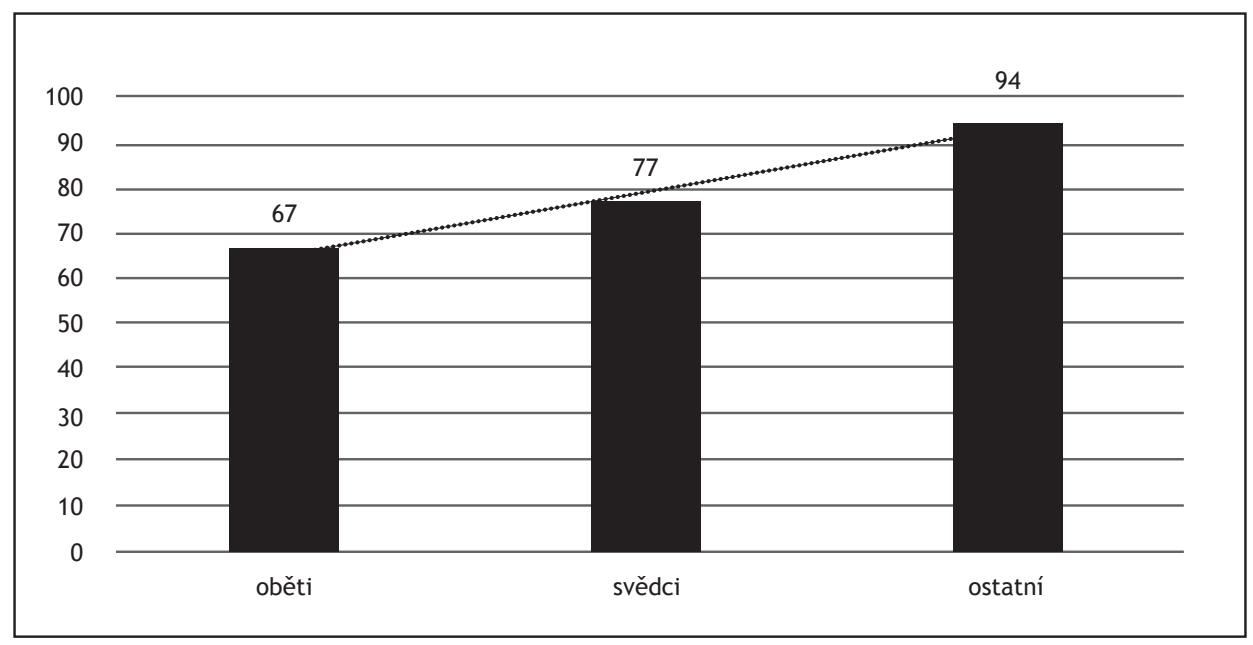

Obrázek 2 Grafické znázornění vnímání klimatu dle zkušenosti s mobbingem 


\subsection{Testování hypotéz}

Další výsledky se týkají testování výzkumných předpokladů. Zjišt’ovali jsme, zda přímá negativní zkušenost s mobbingem, případně i nepřímá zkušenost u přihlížejícího jedince budou ovlivňovat jejich vnímání klimatu. Zaměřili jsme se na analýzu sociálního klimatu na pracovišti s ohledem na různá diferenciační kritéria, jako jsou pohlaví a délka práce.

H1: Ženy-učitelky hodnotí vztahy ve škole signifikantně pozitivněji než muži-učitelé.

Tabulka 3 Komparace vnímání klimatu z hlediska genderových diferencí

\begin{tabular}{|c|c|c|c|c|c|c|c|c|c|}
\hline & $t$-testy; & rupováno & pohlav & Skup & : žena & cup. 2: & & & \\
\hline Proměnná & $\begin{array}{l}\text { Průměr } \\
\text { ženy }\end{array}$ & $\begin{array}{l}\text { Průměr } \\
\text { muži }\end{array}$ & $t$ & sv & $p$ & ženy & muži & $\begin{array}{l}S D \\
\text { ženy }\end{array}$ & $\begin{array}{l}S D \\
\text { muži }\end{array}$ \\
\hline$\Sigma$ klima & 88,7 & 84,1 & 1,68 & 311 & 0,09 & 254 & 59 & 18,21 & 21,06 \\
\hline
\end{tabular}

V tabulce 3 jsou uvedeny výsledky $t$-testu při posuzování genderových diferencí ve vnímání sociálního klimatu u celého zkoumaného vzorku. Z prezentovaných výsledků lze konstatovat ( $p=0,09, a=0,05)$, že vnímání klimatu není významně genderově podmíněné.

H2: Učitelé s delší praxí (nad 20 let) hodnotí klima školy signifikantně pozitivněji než učitelé s kratší praxí.

Tabulka 4 Komparace vnímání klimatu dle délky pedagogické praxe

\begin{tabular}{lcccccccccc}
\hline & \multicolumn{6}{c}{$t$-testy; grupováno: délka zaměstnání. Skup. 1: pod 20 let Skup. 2: nad 20 let } \\
\hline Proměnná & $\begin{array}{l}\text { Průměr } \\
1\end{array}$ & $\begin{array}{l}\text { Průměr } \\
2\end{array}$ & $t$ & $s v$ & $p$ & pod 20 & nad 20 & $\begin{array}{l}\text { SD } \\
\text { pod 20 }\end{array}$ & $\begin{array}{l}\text { SD } \\
\text { nad 20 }\end{array}$ \\
\hline$\Sigma$ klima & 86,7 & 90,5 & $-1,63$ & 311 & 0,10 & 218 & 95 & 19,6 & 16,8 \\
\hline
\end{tabular}

V tabulce 4 jsou prezentovány výsledky vnímání sociálního klimatu u učitelů rozdělených podle délky pedagogické praxe. Zjištěným mediánem byla délka praxe 20 let. Námi naměřená hodnota $t$-testu ukazuje $(p=0,10, a=0,05)$, že není rozdíl ve vnímání klimatu u obou skupin učitelů. Nicméně, na základě průměrů, který u probandů s delší praxí byl vyšší (M 90) než u probandů s kratší praxí (M 86), lze pozorovat určitou tendenci, že učitelé s delší praxí vnímají klima pozitivněji.

H3: Učitelé 1. stupně hodnotí klima školy signifikantně pozitivněji než učitelé na 2. stupni ZŠ.

Na otázku, zda je rozdíl ve vnímání sociálního klimatu mezi učiteli 1. a 2. stupně, odpovídá tabulka 5. Do prvního souboru jsme zahrnuli 129 učitelů působících na 1 . stupni a do druhého souboru 78 učitelů pracujících na 2. stupni. Učitelé, kteří vyučují zároveň na 1. a 2. stupni, byli z tohoto testování vyjmuti. 
120 Tabulka 5 Komparace vnímání klimatu s ohledem na stupeň ZŠ

\begin{tabular}{lllllllllll}
\hline \multicolumn{1}{l}{ t-testy; grupováno: 1. a 2. stupeň } \\
\hline Proměnná & $\begin{array}{l}\text { Průměr } \\
1\end{array}$ & $\begin{array}{l}\text { Průměr } \\
2\end{array}$ & $t$ & sv & $p$ & 1 & 2 & $\begin{array}{l}S D \\
1\end{array}$ & $\begin{array}{l}S D \\
2\end{array}$ \\
\hline$\Sigma$ klima & 89,6 & 88,4 & 0,42 & 205 & 0,67 & 129 & 78 & 18,5 & 19,1 \\
\hline
\end{tabular}

Z tabulky 5 je patrné, že $t$-test shody celkového skóre $v$ obou skupinách nezamítl ( $p=0,67, a=0,05)$, lze tedy konstatovat, že vnímání klimatu na typu školy nezávisí.

H4: Učitelé, kteři se stali obětí mobbingu, hodnotí klima školy signifikantně negativněji než učitelé, kteří se obětí šikany nestali.

Tabulka 6 Komparace vnímání klimatu s ohledem na zkušenost s mobbingem (oběti)

\begin{tabular}{lllllllllll}
\hline \multicolumn{1}{l}{ t-testy; grupováno: pohlaví. Skup. 1: žena Skup. 2: muž } \\
\hline Proměnná & $\begin{array}{l}\text { Průměr } \\
1\end{array}$ & $\begin{array}{l}\text { Průměr } \\
2\end{array}$ & $t$ & sv & $p$ & sk.1 & sk. 2 & $\begin{array}{l}\text { SD } \\
\text { sk. } 1\end{array}$ & $\begin{array}{l}\text { SD } \\
\text { sk. 2 }\end{array}$ \\
\hline$\Sigma$ klima & 88,8 & 66,2 & 4,34 & 311 & 0,00 & 300 & 13 & 17,8 & 28,1 \\
\hline
\end{tabular}

V tabulce 6 jsou prezentovány výsledky vnímání klimatu u obětí mobbingu a učitelů bez této negativní zkušenosti. Statistický test významnosti rozdílů potvrdil rozdíl ve vnímání sociálního klimatu $(p=0,00, a=0,05)$. Test rozdílů průměrných skórů mezi oběma podsoubory mobbovaných a nemobbovaných zaměstnanců poukazuje na skutečnost, že oběti mobbingu vnímají klima v pedagogickém sboru signifikantně negativněji v porovnání s kolegy, kteří mobbingu nebyli vystaveni. Obrázek 3 vizualizuje numerická data pomocí jejich kvartilů.

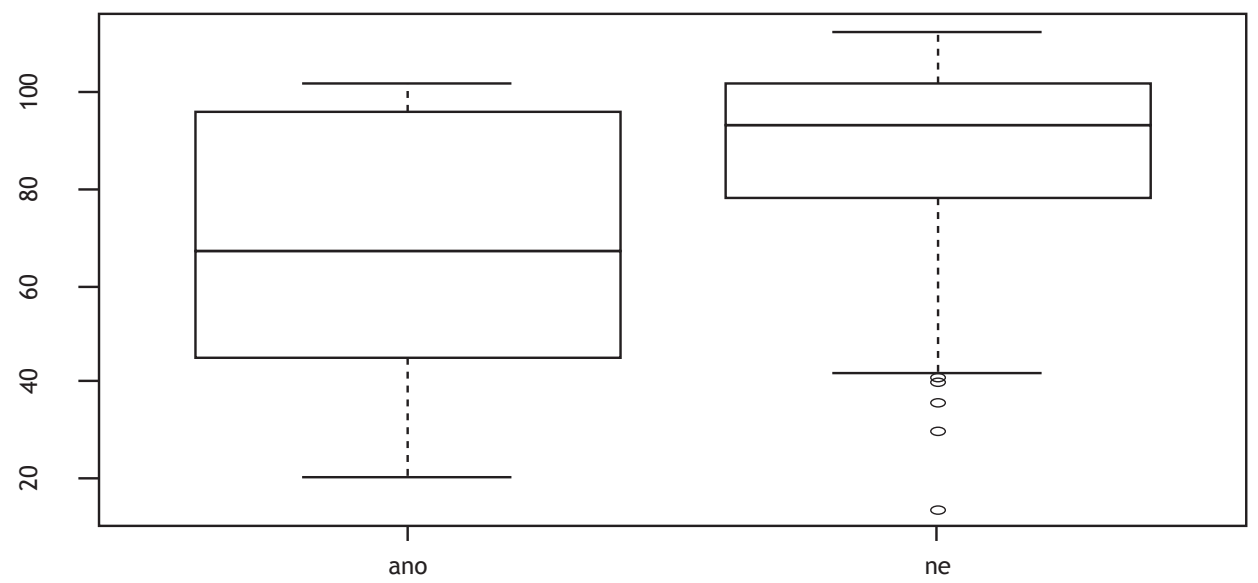

Obrázek 3 Vizualizace numerických dat - boxplot 
H5: Učitelé, kteři byli svědky mobbingu, hodnotí klima školy signifikantně negativněji než učitelé, kteří svědky nebyli.

Tabulka 7 Komparace vnímání klimatu s ohledem na zkušenost s mobbingem (svědci)

\begin{tabular}{|c|c|c|c|c|c|c|c|c|c|}
\hline \multicolumn{10}{|c|}{$t$-testy; grupováno: svědek mobbingu. Skup. 1: není svědek Skup. 2: svědek } \\
\hline Proměnná & $\begin{array}{l}\text { Průměr } \\
1\end{array}$ & $\begin{array}{l}\text { Průměr } \\
2\end{array}$ & $t$ & sv & $p$ & $\begin{array}{c}\text { není } \\
\text { svědek }\end{array}$ & svědek & $\begin{array}{l}\text { SD } \\
\text { není svědek }\end{array}$ & $\begin{array}{l}S D \\
\text { svědek }\end{array}$ \\
\hline$\Sigma$ klima & 89,2 & 74,7 & 4,03 & 31 & 0,00 & 284 & 29 & 18,1 & 21,3 \\
\hline
\end{tabular}

Tabulka 7 prezentuje výsledky statistického testu rozdílů ve vnímání sociálního klimatu u svědků šikany a učitelů, kteří nebyli vystaveni takové zkušenosti. Podobně jako $v$ tabulce 6 vnímají svědci šikany sociální klima jako výrazně horší než respondenti, kteří tuto negativní zkušenost nemají $(p=0,00, a=0,05)$. Obrázek 4 vizualizuje numerická data vztahující se k tabulce 7 .

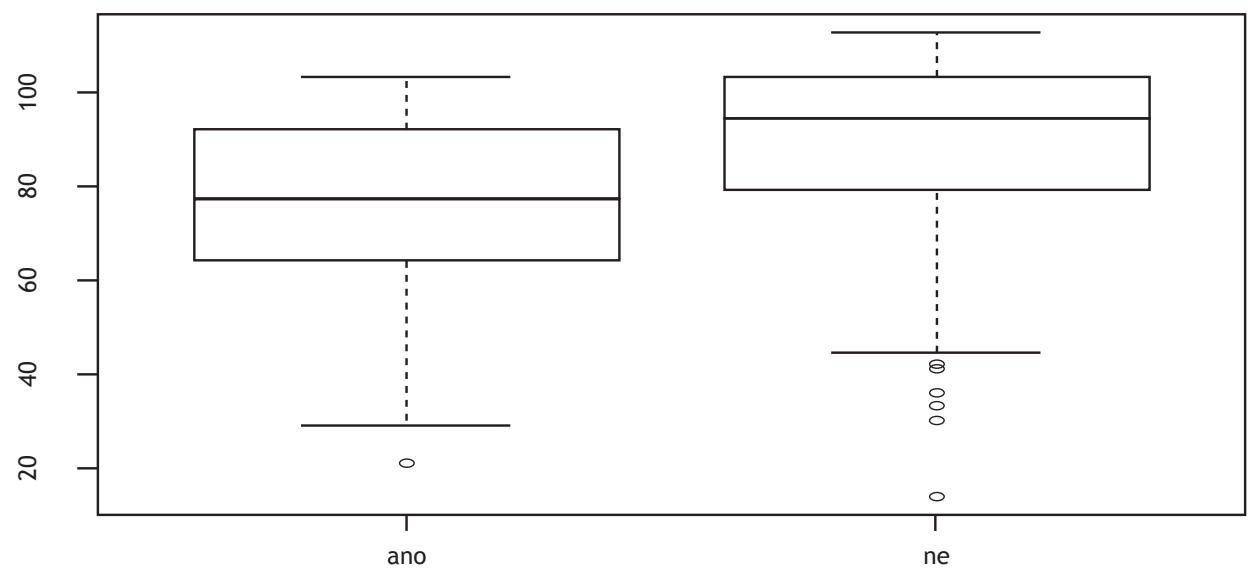

Obrázek 4 Vizualizace numerických dat - boxplot

\section{Diskuse}

Školu chápeme v souladu s Urbánkem (2008) jako sociální skupinu, jejíž podstatou fungování, rozvoje a kvality je vztahový rámec tvořený všemi zainteresovanými aktéry. Zabývání se kvalitou klimatu školy a aspekty, které ji spoluutváří a ovlivňují, se jeví jako jeden z vhodných ukazatelů potenciálu pro navození žádoucích změn v rámci celé školy.

V naši studii jsme se věnovali vztahovému faktoru uvnitř školy, konkrétně klimatu $\checkmark$ rámci pedagogického sboru, respektive analýze sociálního klimatu s ohledem na různé proměnné. Konkrétně nás zajímalo, zda se zkušenost s mobbingem u respon- 
122 dentů může promítnout do vnímání sociálního klimatu na pracovišti. A především, zda i pouhá nepřímá zkušenost, to znamená, když je respondent pouze svědkem situace, kdy je jiný pedagog šikanován spolupracovníkem či vedoucím pracovníkem, bude mít vliv na subjektivní posouzení klimatu na pracovišti. Dosavadní tuzemské výzkumné studie se problematikou svědků mobbingu príliš nezabývají a v tomto ohledu výzkum rozšiřuje tuto oblast o nové poznatky.

Neprokázal se statisticky významný rozdíl ve vnímání sociálního klimatu z hlediska genderu. Při porovnávání respondentů se zkušeností s mobbingem byly odhaleny jisté genderově podmíněné diference, ale jednalo se o statisticky nevýznamné rozdíly. Je však nutno podotknout, že by bylo vhodné genderové diference sledovat i nadále na větším vzorku a pokud možno intersexuálně vyváženém. Na důležitost genderového faktoru poukazuje i Salinová (2011), která akcentuje rozdíly v chování žen a mužů v situacích, kdy jsou přítomni šikanování jiného pedagoga. Na základě sociální teorie se vysvětluje rozdílnost např. v pomáhajícím chování u mužů a žen v situaci, kdy jsou př́tomni šikanujícímu chování vůči jinému pedagogovi.

Při analýze sociálního klimatu u 313 členů pedagogických sborů jsme zjistili, že pedagogové 1. a 2. stupně ZŠ z našeho monitorovaného vzorku vnímají sociální klima jejich pracoviště celkově jako pozitivní. Konkrétně téměř tři čtvrtiny dotázaných hodnotí klima pozitivně, což koresponduje s výsledky výzkumu Čecha (2011). Pětina respondentů zaujímá neutrální postoj a necelých 7 \% vnímá klima spíše negativně. Pokud porovnáme vnímání sociálního klimatu mezi obět'mi, svědky a ostatními pedagogy bez zkušenosti s mobbingem, mưžeme konstatovat, že oběti vnímají sociální klima hưře než svědci a než pedagogové bez zkušenosti. Tuto skutečnost, že nejen oběti, ale i svědci vnímají své pracovní prostředí negativněji než pedagogové bez zkušenosti, zmiňují i některé zahraniční studie (např. Vartia, 1996). Vartiaová (2001) v následném výzkumu potvrzuje i větši míru obecného a psychického stresu u pedagogů se zkušeností s mobbingem. Twemlow, Fonagy a Sacco (2005) vnímají šikanu ne jako dyadickou, ale jako triadickou interakci zakotvenou v sociálních rolích.

Dosavadní zahraniční empirické studie se zamýšlejí nad tím, jestli faktory, jako jsou pracovní zátěž (Salin, 2003), konflikt rolí (Einarsen, Raknes, \& Matthiesen, 1994) nebo chování vedení (Einarsen, 2000), ovlivňují mobbing na pracovišti přímo nebo zda přispívají $k$ vytváření stresového pracovního klimatu, kde se šikaně může tzv. dobře dařit. Mezi faktory, které se $\mathrm{k}$ šikaně vztahují, také někteří autoři přidávají sociální klima (Hoel \& Cooper, 2000; Agervold \& Mikkelsen, 2004).

Nekvalitní sociální prostředí mǔže často hrát kličcovou roli při vyvolání či usnadnění vzniku negativních forem chování na pracovišti (Hoel \& Einarsen, 1999).

Z důvodu zachování anonymity nebylo možné rozlišit respondenty, kteří spadají do stejné školy, respektive ke stejnému pedagogickému sboru, což vnímáme jako jistý limit při interpretaci. Také je třeba zmínit genderovou diskrepanci, která ovšem reflektuje přirozeně se vyskytující poměr, respektive nepoměr zastoupení mužů $\checkmark$ pedagogickém povolání.

$\checkmark$ rámci limitů výzkumu je třeba podotknout, že internet jako prostředek pro relevantní sběr dat má jistá omezení, která je třeba zvážit při interpretaci vý- 
sledků. Především se to týká motivace zapojit se do výzkumu, jakým je šikana na pracovišti.

Jisté limity přináší i volba dotazníkové metody šetření tak složitého a citlivého fenoménu, jakým je mobbing. Přestože dotazník negativních aktů (NAQ-R) má uspokojivé psychometrické vlastnosti, metoda dotazování není schopna postřehnout motivační, emoční a další psychické pochody hlavních aktérů mobbingu.

\section{Závěr}

Je zřejmé, že mobbing musíme považovat za závažný etický problém, který zasahuje do života současných škol a zásadním zpưsobem ovlivňuje osobnost učitele-oběti nebo učitele-svědka, jeho pracovní výkon i soukromý život. Z výzkumu je zřejmé, že reakce učitele na šikanu na pracovišti jsou rozdílné vzhledem k dalším okolnostem jejich profesního i osobního života (věk, pohlaví, starost o rodinu, možnost nalézt novou práci, existenční závislost na pracovním místě atp.), ve většině mají obdobné fáze vývoje, jen s rozdílným vyústěním.

S tímto konstatováním rozhodně nelze problematiku uzavřít, ale je třeba z preventivního hlediska prohloubit mezi pedagogy informovanost, a to nejen z hlediska povědomí o fenoménu, ale také o možnostech obrany a znalosti právních norem. Současně by každá škola měla přijmout etický kodex učitele a stanovisko k možnému výskytu mobbingu jako k neakceptovatelné formě chování v pedagogickém prostředí.

\section{Literatura}

Agervold, M., \& Mikkelsen, E. G. (2004). Relationships between bullying, psychosocial work environment and individual stress reactions. Work \& Stress, 18(4), 336-351.

Anderson, C. S. (1982). The search for school climate: A review of the research. Review of Educational Research, 52(3), 368-420.

Beňo, P. (2003). Můj šéf, můj nepřitel? Šlapanice: Era.

Bulach, C., \& Malone, B. (1994). The relationship of school climate to the implementation of school reform. Ers Spectrum, 12(4), 3-8.

Cakirpaloglu, P., Šmahaj, J., Dobešová Cakirpaloglu, S., \& Zielina, M. (2016). Šikana na pracovišti $v$ České republice: Teorie, výzkum a praxe. Olomouc: UP.

Cakirpaloglu, P., Šmahaj, J., Dobešová Cakirpaloglu, S., \& Zielina, M. (2017). Šikana na pracovišti: Reliabilita a validita českého překladu revidované verze dotazníku negativních aktů NAQ-R. Československá psychologie, 61(6), 546-558.

Čech, T. (2010). Mobbing v základních školách jako etický problém. E-pedagogium, 10(2), 9-19.

Čech, T. (2011). Mobbing jako negativní fenomén v prostředí základních škol. Brno: MU.

Čech, T., Dobešová Cakirpaloglu, S., \& Kvintová, J. (2017). Workplace bullying - coping strategies of teachers. In P. A. da Silva Pereira, O. Titrek, \& G. Sezen-Gultekin (Eds.), Iclel 17 conference proceeding book (s. 416-424). Sakarya: Sakarya University.

Čech, T., \& Kantor, D. (2010). Fenomén mobbingu a bossingu v českých školách. Mládež a spoločnost', 16(1), 64-78. 
124 Dobešová Cakirpaloglu, S., Čech, T. , \& Kvintová, J. (2017). The incidence of workplace bullying in Czech teachers. In P. A. da Silva Pereira, O. Titrek, \& G. Sezen-Gultekin (Eds.), Iclel 17 conference proceeding book (s. 425-431). Sakarya: Sakarya University.

Einarsen, S. (2000). Harasment and bullying at work: A review of the Scandinavian approach. Agression and Violent Behavior, 5(4), 379-401.

Einarsen, S., Hoel, H., \& Notelaers, G. (2009). Measuring exposure to bullying and harassment at work: Validity, factor structure and psychometric properties of the Negative Acts Questionnaire-Revised. Work \& Stress, 23(1), 24-44.

Einarsen, S., Hoel, H., Zapf, D., \& Cooper, C. L. (2011). The concept of bullying and harassment at work: The European tradition. In S. Einarsen, H. Hoel, D. Zapf, \& C. L. Cooper (Eds.), Bullying and harassment in the workplace: Developments in theory, research, and practice (s. 3-40). London: Taylor \& Francis.

Einarsen, S., Raknes, B. R. I., \& Matthiesen, S. B. (1994). Bullying and harassment at work and their relationships to work environment quality: An exploratory study. European Journal of Work and Organizational Psychology, 4(4), 381-401.

Grecmanová, H. (2003). Klima školy v německé pedagogické literatuře. In S. Ježek (Ed.), Psychosociální klima školy I (s. 75-86). Brno: MU.

Grecmanová, H. (2008). Klima školy. Olomouc: Hanex.

Halpin, A. W. , \& Croft, D. B. (1963). The organizational climate of schools. Chicago: University of Chicago.

Hoel, H., \& Cooper, C. L. (2000). Destructive conflict and bullying at work. Manchester: Manchester School of Management, UMIST.

Hoel, H., \& Einarsen, S. (1999). Workplace bullying. John Wiley \& Sons.

Høgh, A., Hansen, A.. M., Mikkelsen, E. G., \& Persson, R. (2012). Exposure to negative acts at work, psychological stress reactions and physiological stress response. Journal of Psychosomatic Research, 73(1), 47-52.

Ježek, S. (Ed.). (2003). Psychosociální klima školy I. Brno: MSD.

Keashly, L., \& Jagatic, K. (2011). North American perspectives on hostile behaviors and bullying at work. In S. Einarsen, H. Hoel, D. Zapf, \& C. L. Cooper (Eds.), Bullying and harassment in the workplace: Developments in theory, research, and practice (s. 41-71). London: Taylor \& Francis.

Kelley, R. C., Thornton, B., \& Daugherty, R. (2005) Relationships between measures of leadership and school climate. Education, 126(1), 17-25.

Kivimäki, M., Virtanen, M., Vartia, M., Elovainio, M., Vahtera, J., \& Keltikangas-Järvinen, L. (2003). Workplace bullying and the risk of cardiovascular disease and depression. Occupational and Environmental Medicine, 60(10), 779-783.

Kottkamp, R., \& Mulhern, J., \& Hoy, W. K. (1987). Secondary school climate: A revision of the OCDQ. Educational Administration Quarterly, 23(3), 31-48.

Lašek, J. (2007). Sociálně psychologické klima školních tříd a školy. Hradec Králové: Gaudeamus.

Leymann, H. (1996). The content and development of mobbing at work. European Journal of Work and Organizational Psychology, 5(2), 165-184.

Lutgen-Sandvik, P. (2013). Adult bullying - a nasty piece of work: Translating a decade of research on non-sexual harassment, psychological terror, mobbing, and emotional abuse on the job. St. Louis: ORCM Academic Press.

Mareš, J., \& Křivohlavý, J. (1995). Komunikace ve škole. Brno: MU.

Moayed, F. A., Daraiseh, N., Shell, R., \& Salem, S. (2006). Workplace bullying: A systematic review of risk factors and outcomes. Theoretical Issues in Ergonomics Science, 7(3), 311-327.

Nielsen, M. B., \& Einarsen, S. (2012). Outcomes of exposure to workplace bullying: A meta-analytic review. Work \& Stress, 26(4), 309-332.

Paull, M., Omari, M., \& Standen, P. (2012). When is a bystander not a bystander? A typology of the roles of bystanders in workplace bullying. Asia Pacific Journal of Human Resources, 50(3), 351-366. 
Pekrun, R. (1985). Schulklima. In W. Twellmann (Ed.), Handbuch Schule und Unterricht (s. 524-547). Düsseldorf: Schwann.

Petlák, E. (2006). Klíma školy a klíma triedy. Bratislava: Iris.

Salin, D. (2001). Prevalence and forms of bullying among business professionals: A comparison of two different strategies for measuring bullying. European Journal of Work and Organizational Psychology, 10(4), 425-441.

Salin, D. (2003). Ways of explaining workplace bullying: A review of enabling, motivating and precipitating structures and processes in the work environment. Human Relations, 56(10), 1213-1232.

Salin, D. (2011). The significance of gender for third parties' perceptions of negative interpersonal behaviour: Labelling and explaining negative acts. Gender, Work \& Organization, 18(6), 571-591.

Sekera, J., \& Janáček, Z. (1994). Hodnotová orientace a mezilidské vztahy $v$ pedagogických sborech. Ostrava: OU.

Svobodová, L. (2008). Nenechte se šikanovat kolegou. Mobbing - skrytá hrozba. Praha: Grada.

Thomas, A. R. (1976). The organizational climate of schools. International Review of Education, 22(4), 441-463.

Twemlow, S. W., Fonagy, P., \& Sacco, F. C. (2005). A developmental approach to mentalizing communities II. The peaceful schools experiment. Bulletin of the Menninger Clinic, 69(4), 282-304.

Urbánek, P. (2003a). K metodologickým otázkám měření klimatu učitelských sborů. In S. Ježek (Ed.), Psychosociální klima školy I (s. 123-134). Brno: MU.

Urbánek, P. (2003b). Měření klimatu školy a učitelského sboru v českém prostředí základní školy. (Příprava aplikace dotazníku OCDQ-RS.) In Sociální a kulturní souvislosti výchovy a vzdělávání. 11. výroční mezinárodní konference ČAPV. Brno: MU. [CD-ROM] Dostupné též z https: / /www.ped.muni.cz/capv11/default0.htm

Urbánek, P. (2006). Klima učitelských sborů ZŠ: Empirická zjištění. In M. Kocurová (Ed.), Současné metodologické přistupy a strategie pedagogického výzkumu. 14. konference ČAPV. Plzeň: ZČU. Dostupné z http://www.kpg.zcu.cz/capv/HTML/105/default.htm

Urbánek, P. (2008). Klima učitelského sboru v případové studii základní školy. Orbis scholae, 2(3), 87-106.

Vartia, M. (1996). The sources of bullying: Psychological work environment and organizational climate. European Journal of Work and Organizational Psychology, 5(2), 203-214.

Vartia, M. (2001). Consequences of workplace bullying with respect to the well-being of its targets and the observers of bullying. Scandinavian Journal of Work, Environment \& Health, 27(1), 63-69.

Vartia, M. (2003). Workplace bullying: A study on the work environment, well-being and health (Nepublikovaná disertační práce). Helsinky: UH. Dostupné z http: / /ethesis. helsinki. fi/julkaisut/hum/psyko/vk/vartia-vaananen/workplac.pdf

Vignoli, M., Guglielmi, D., Balducci, C., \& Bonfiglioli, R. (2015). Workplace bullying as a risk factor for musculoskeletal disorders: The mediating role of job-related psychological strain. BioMed Research International, 2015(2), 712642.

Walberg, H. J. (1972). Social environment and individual learning: A test of the Bloom model. Journal of Educational Psychology, 63(1), 69-73.

Zapf, D., Escartín, J., Einarsen, S., Hoel, H., \& Vartia, M. (2011). Empirical findings on prevalence and risk groups of bullying in the workplace. In S. Einarsen, H. Hoel, D. Zapf, \& C. L. Cooper (Eds.), Bullying and harassment in the workplace: Developments in theory, research, and practice (s. 75-105). London: Taylor \& Francis.

doc. PhDr. Tomáš Čech, Ph.D., Ústav pedagogiky a sociálních studií Pedagogická fakulta, Univerzita Palackého v Olomouci Žižkovo náměstí 5,77140 Olomouc tomas.cech@upol.cz 
Mgr. Simona Dobešová Cakirpaloglu, Ph.D., katedra psychologie a patopsychologie Pedagogická fakulta, Univerzita Palackého v Olomouci Žižkovo náměstí 5,77140 Olomouc simona.dobesova@upol.cz

PhDr. Jana Kvintová, Ph.D., katedra psychologie a patopsychologie Pedagogická fakulta, Univerzita Palackého v Olomouci Žižkovo náměstí 5, 77140 Olomouc jana.kvintova@upol.cz 